\title{
Whose Past and Whose Future: \\ Free Love and Love Marriage among "Kafirs" of the Hindukush in an Early Nineteenth-Century Persian Ethnography
}

\author{
Alberto Cacopardo \\ University of Florence \\ Stefano Pellò \\ "Ca' Foscari" University of Venice
}

\begin{abstract}
This paper deals with some practices and conceptions relating to love and marriage in a now-extinct pre-Islamic culture of the Hindukush, as described in an extremely precious, yet very little-known, Persian ethnographical source (ca. 1840). Written by a munshī from Peshawar under instructions from the French general Claude-Auguste Court, who was then in the service of Maharaja Ranjit Singh, this is probably the single most important pre-Robertson source about the "Kafir" cultures of Nuristan. While a complete translation and thorough study of the unpublished document, by Stefano Pellò and Alberto Cacopardo, is now forthcoming, in these brief notes we show how free love and love marriage, often perceived as "modern" concepts in many parts of Asia, were envisioned by Tak and Shamlar, two elders from pre-Islamic Kamdesh.
\end{abstract}

Keywords

Love and Marriage among Kafirs, Adultery and Pre-Marital Sex, Elopement, Hindukush, Kafiristan, Kalasha, Nuristan, Persian Ethnography

It is well known that, in many parts of Asia, the idea of marriage based on mutual affection rather than on parents' choice has become in recent decades a core element in the ideology of modernity. There is a prevalent feeling that the youths' aspirations to free choice are something that belongs to the future, while the resistances of old-fashioned parents definitely belong to the past. In other words, it seems very often taken for 
granted that, in this sphere, the "West" is the future of the "Rest".

In her contribution to a collection of essays documenting this phenomenon, however, Winnie Maggi argued years ago that among the nonMuslim Kalasha of northern Pakistan, things are quite different. Here "[t]he cultural right that young Kalasha people claim to translate love and longing into marriage [...] is a central marker of Kalasha ethnicity" (Maggi 2006: 82), definitely "not a response to modernity" (ibid.: 86).

Kalasha women's agency has been analyzed in depth by Maggi in a valuable work by the eloquent title of Our Women are Free (Maggi 2001). It is expressed in a variety of ways, but a central position in the culture is held by the institution of alasing, by which women have the recognized right to forsake their husband by eloping with another man of their choice. Rather than unleashing a bloody feud between families, this will lead to long negotiations about the compensation to be paid to the husband, which is traditionally reckoned as double the bridewealth he originally paid to the wife's family.

The right to elopement, however, is only one element in the picture. To get a clear view of the women's agency in the sphere of romance, sex and marriage, we need to look beyond the specific motif of alașing, and distinguish at least four different points: 1) the weight of the women's wishes in the original choice of their marriage partners; 2 ) their capacity to dissolve their marriage if unsatisfied with it; 3) the attitudes towards their possible adulterous relationships; and 4) their freedom to entertain premarital romance and sexual relationships. The first two directly relate to "love marriage", the others to what can be labelled "free love", if we may resort to this venerable cliché once dear to old-time anarchists.

In synthesis (and with some simplification), among present-day Kalasha: the right of married women to elope with a man of their choice has ambiguous effects on their parents' decisions about their original marriage; elopement is very frequent and is central to a sort of ideology of love marriage and women's free choice; adulterous relations are quite

\footnotetext{
${ }^{1}$ The notion of "West" is, of course, a fairly recent cultural construct that is loaded with a host of questionable implications, which cannot be discussed here (cf. on this, for just one example, Graeber 2007: 332ff.). For this reason, we put it in quotes, while recognizing that it has acquired a weight in the collective imagination of our age that warrants its narrative employment, albeit with a certain vein of irony.
} 
common, can cause trouble but not bloodshed, and can be sanctioned through compensation only when (rarely) discovered in flagrance; there is no formal sanction for premarital sex, and female virginity is not rated a value (cf. Parkes 1983: 546ff.; Maggi 20o1: 167-212). Altogether, we can say that "love marriage" is a normal fact with the Kalasha, and that "free love" is practiced in forms quite similar to "Western" contexts. The question is: is all this really part of a long-standing ethnic heritage? According to Peter Parkes (1983: 572), this is far from certain. Unfortunately, there is no written document on Kalasha culture prior to the 2oth century to prove it.

From the cultural-historical point of view, the issue has a relevance that far transcends the history of the few thousand Kalasha living today, because these people are the last remnant of a much larger cultural complex of Indo-European ascendance that once extended across the Hindukush/Karakorum from the Kabul Kohistan to the edge of Kashmir. This is the "Greater Kafiristan" of the Middle Ages, a veritable "counter-civilization" that has come to be referred to with the label "Peristan". 'Geographically located on the very permeable Indo-Iranian cultural and linguistic limes, this "Indian Caucasus" of the ancients was perceived in early modern times as an extreme periphery of the cultural net of the Persosphere, but was in fact a world of its own, with a deep-historical heritage of confrontation and variable interplay with both sides of that frontier.

If the Kalasha women's agency in matters of love and marriage is not a relatively recent development of their own local history, then we ought to be able to find traces of it in the now extinct "Kafir" cultures of the rest of Peristan, and particularly those of nearby Nuristan, about which we do have the well-known testimony of Robertson and other writers of precolonial and colonial times.

These sources, however, are fragmentary, inexhaustive, and mostly heavily conditioned by their male authors' Victorian frame of mind. Robertson (1896) is particularly disappointing on such matters: though he does have some hints about adultery and pre-marital sex, he shows very little knowledge about marriage in all its aspects, discusses "divorce" in a

\footnotetext{
${ }^{2}$ See Cacopardo/Cacopardo 2001; Cacopardo 2019: 33ff; idem 2022 (in press). "Kafir", meaning "pagan" in Arabic/Persian, was the label applied to all these peoples by their Muslim neighbours before they were converted to Islam.
} 
confusing and male-centered fashion, and mentions elopement only passingly. Our best source about marriage is the famous "Azar manuscript" (Azar 2006), ${ }^{3}$ which treats the procedures with some detail and also discusses adultery, though not an elopement. Other pre-Robertson sources on the subject are occasionally useful, but mostly fragmentary or dubious.

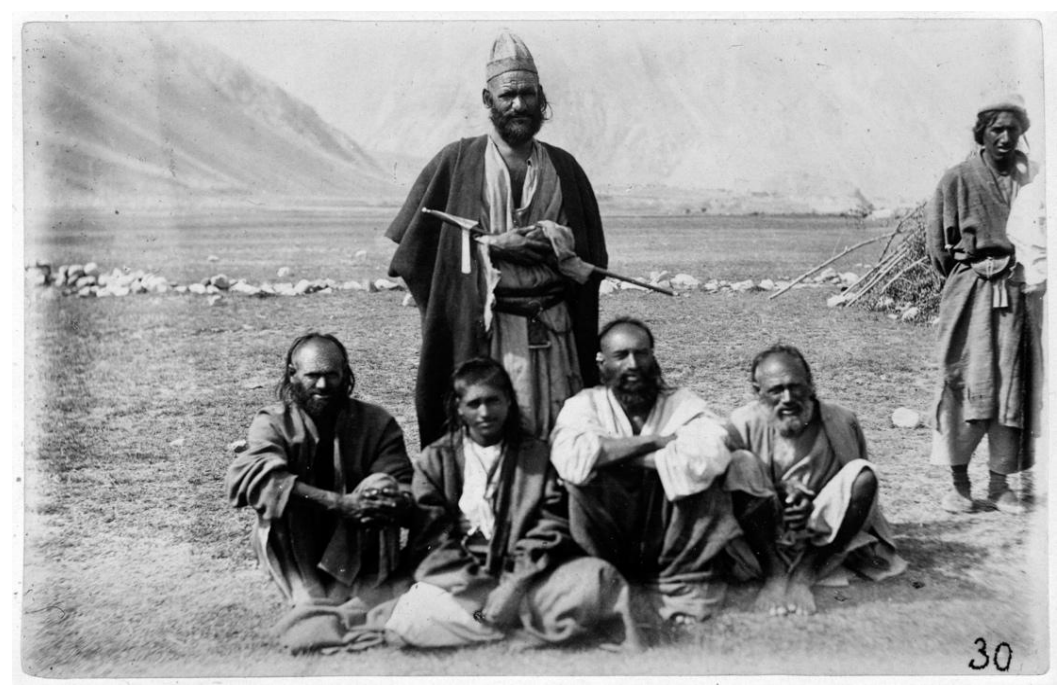

A group of Kafirs from Kamdesh photographed by the Lockhart mission in 1885

A welcome addition to our knowledge, therefore, comes now from a so-far unpublished document that is probably the single most important pre-Robertson source about the pre-Islamic cultures of Nuristan. This is the Persian manuscript compiled around 1840 by Hầjī Allāhdād, a munshī from Peshawar, under instructions from the French general ClaudeAuguste Court, ${ }^{4}$ who was then in the service of Maharaja Ranjit Singh. Allāhdād, a Pashto-speaking, Persian-writing provincial man of letters clearly educated in a still dominant late Mughal Stimmung (Pellò 2009), traveled to the town of Dir, where the local Pashtun ruler summoned two

${ }^{3}$ This important autoethnographic manuscript was written by a young, freshly converted Kafir around 1908 and was acquired by Georg Morgenstierne in 1929. It concerns the Kati of upper Bashgal, a Nuristani group neighbouring both the Kalasha and the Kom of lower Bashgal, the group of Tak and Shamlar (see further), with which they had much in common.

${ }^{4}$ On Court, better than the classic Grey 1929: 148-16o, see Lafont 1992; idem 2000: 205$214,287-342$. 
elders from Kamdesh, Tak and Shamlar, to answer a long list of questions prepared by the general — and translated (and re-organized) in Persian by Allāhdād—on their culture, religion and social organization. ${ }^{5}$

The result is an extraordinary document, recording almost "live" an exceptional intercultural dialogue. The text has a highly structured form. After a brief introduction describing the circumstances of the encounter, we find, to the left, a continuous list of questions on the verso of each folio, with the corresponding answers to the right, on the recto of the next folio. Each batch of answers is presented in a continuous form, in coordinated sentences linked by the conjunction $w a$, giving the impression of a continuous flow of speech: but to closer scrutiny, we find that there is mostly, with few exceptions, a close correspondence between every single question and every single answer.

This is why, in presenting here a brief selection of passages relating to women's agency and conditions, we have chosen to break down the original structure of the document into a discontinuous succession of questions and answers, in order to highlight the correspondence between the two and obtain a text that is likely to reflect more closely the original oral form of the dialogue. Our comments follow each Q\&A couplet. The selected questions are presented in the order in which they appear in the manuscript. For their contextual collocation, the reader will have to refer to the coming publication of the full text (Cacopardo/Pellò, forthcoming).

[f. 1ob] At what age do they arrange (missäzand) the marriage of the boy (katkhudāyli-i pisar)?

[f. 13a] When he reaches puberty (bāni') he is made to marry (katkhudāyīi ū mīkunand).

The process of marriage was actually a long and complex affair, involving a number of successive steps. ${ }^{6}$ Tak and Shamlar apparently refer here to the moment when the marriage agreement was reached between the families through the mediation of their lineage elders, and the amount of

\footnotetext{
${ }^{5}$ Full text and translation of the manuscript will soon be published by the present authors in Cacopardo/Pellò (forthcoming), along with the Notice sur le Kafféristan that Court wrote on its basis and left unpublished (Court n.d.). On the Allāhdād document, see also Holzwarth 1994 and Pellò 20og.

${ }^{6}$ For which see Azar (2006: 12-16), with all the other references.
} 
bridewealth was determined - which is probably what Robertson (1896: 534) also meant when he noted that most girls were married by twelve.

[f. 11b] How do they celebrate marriage (shādī)? Do they marry (katkhudāȳ mīs $\bar{a}-$ zand) only one woman or two or three more?

[f. 13a] There is no rigid rule as far as taking wife is concerned, it depends on the wealth (dawlat), he can take as many as he wants according to what his wealth allows, and they have a lot of sexual energy (quwwat-i bāh).

In Robertson's time, all men of any standing had more than one wife (Robertson 1896: 534-35), indicating that Kamdesh must have been a fairly wealthy community. The unsolicited remark about the abundant sexual energy is in itself symptomatic of the culture's attitude toward sex.

[f. 11b] If someone has a wife and from her womb (baṭn) a child is never born can he repudiate (țalāq dādan) her or not?

[f. 14a] If the woman is barren ('aqima), i.e., has no child, the man is free to take as many women as he desires (ikhtiyār dārad).

As with the Kalasha, repudiating a wife would be a serious setback for a husband, because he would lose both the bridewealth paid for her and, even worse, her precious work in the fields (cf. Parkes 1983: 558; Maggi 2001: 185ff.). The gendered division of labour in pre-Islamic Peristan, assigning farming to women and herding to men, made the spouses strictly complementary for their very subsistence. Thus, a displeased husband's only reasonable option was to fetch another wife, as long as he could afford it.

[f. 11b] And among them is there the word (for) țalāq (lafz-i țalāq) or not?

[f. 14a] There is no word (for) țalāq, and they do not practice it.

Robertson (1896: 536-37) apparently had a lot of trouble understanding divorce, because he did not grasp the point made above, and had to conclude that "Kafirs rarely divorce their wives unless the women run away from them", without being able to explain why. In Tak and Shamlar's version, repudiation by the husband (talāq in Islamic fiqh) was simply not contemplated by their custom.

[f. 12b] For instance, if someone marries and is impotent (nāmard) or the woman has an incapacitating disease ('illat) affecting her femininity (kār-izanān), do they 
consider it bad or not? Can they repudiate (țalāq dādan) for these two reasons or not? How do they find a solution?

[f. 14a] If a man is impotent the woman is free to choose anyone she wants to do [the work of] the husband. For both the two diseases that prevent intercourse or for infertility there is no talāq.

The two elders consider first the woman's position: it is not quite clear if they mean that she is free to entertain adulterous relationships without need of compensation to the husband, or that she is free to choose another husband. The former instance cannot be ruled out, but it is not attested by any other source; the latter was probably true in any case. Then the elders reiterate and confirm their previous statement: thus, while the woman in this case is free to do without her husband, the man, in the specular instance, is not free to repudiate her. Of course, he is always free to get another wife.

\footnotetext{
[f. 12b] If the son of someone wants to decide for his own marriage ('arūs $\bar{l}$ ), can the father and the mother force him to marry [according to their will] ( $b a$ zür katkhudāyli-yi $\bar{u}$ kardan)? And the son who without the permission of the father and the mother gets married following his own will (ba marzil-yi khwad) is considered guilty (gunahkār) or not?

[f. 14a] If the son takes a wife following his own will there is no problem, although the other people will criticize him. And if the father and the mother give their daughter to the husband by force without her consent, she will kill herself.
}

In the silence of Robertson on this point, this answer is crucial to the issue of love marriage: if the boy follows "his own will", there is no problem, except for some probably harmless criticism. But that is not all: while Allāhdād/Court only ask about the boy, apparently not even considering that the girl might have any say, the two elders spontaneously extend their reply to the case of the woman. Here their dramatic statement begs interpretation: that any girl should ever kill herself in such circumstances seems really quite improbable. It is more likely that she would threaten to kill herself, which may have been a standard verbal strategy in these cases. The actual meaning is quite clear: marriages were simply not arranged against the will of the girl. This is largely corroborated by the Azar manuscript (Azar 2006: 12). The girl's consent, in particular, had to be formally requested once the agreement between parents was formed (ibid.: 13-14). 
[f. 16b] If a woman behaves lasciviously (fähisha shud) and desires (rāghib gardīd) someone else, how is she punished by her husband?

[f. 18a] As for the lascivious woman they do like this: they place two sticks standing and make the woman pass between them, if the sticks move the punishment is that they take from the man the value of four tūmān and they hack down a pillar in the house and tread on his gardens.

Another key question. Note that whereas the inquiry is about punishment for the woman, in the answer she is only the subject of an ordeal as a means of proof, while the punishment is for her lover. This is in line with our other sources, which describe the woman's punishment as either slight (Biddulph 1880: 133; Robertson 1896: 537; Azar 2006: 23; cf. also Elphinstone 1815: 624), or altogether inexistent (Hughes 1883: 408). Tak and Shamlar also agree with the other sources on the fact that, unlike with the Pashtun code, where killing the adulterer is mandatory to preserve the husband's honour, here retaliatory murder of the offender was simply not allowed. As Jones (1974: 157) recorded in Waigal: "In Kafir times we did not kill a man and a woman if they committed adultery. This idea came from the Muslims [...] In Kafir times there was a fine for adultery, not killing".

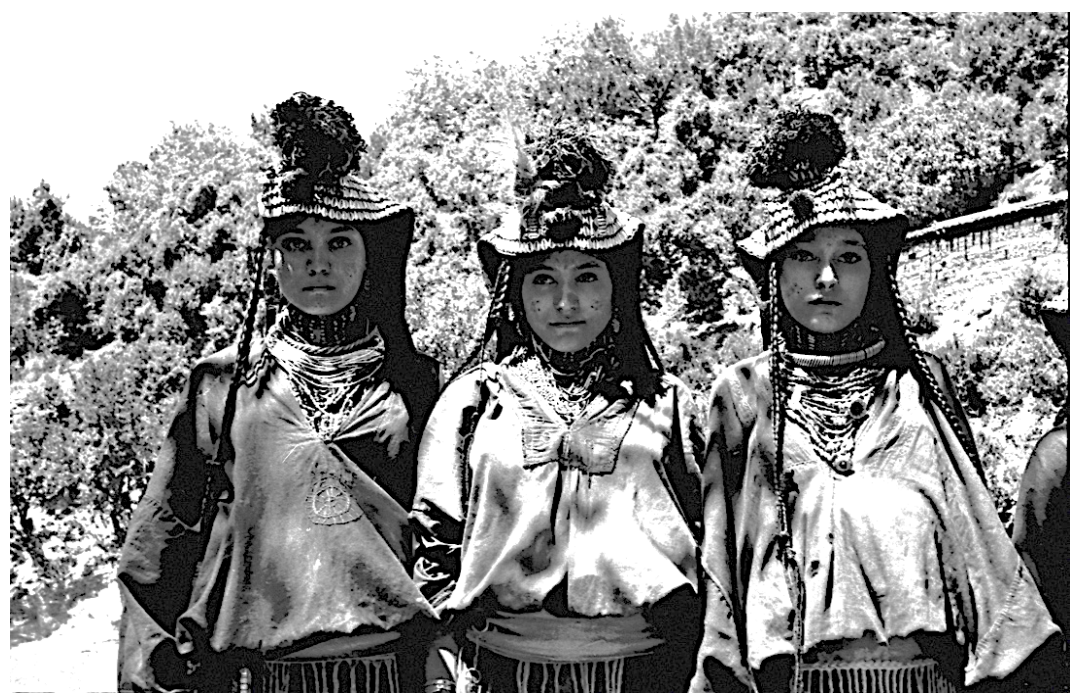

Three Kalasha girls photographed in 1962 by Michael Selzer.

The typical kupas headdress is covered with cowrie shells from the Indian ocean, once used in India as fractional currency 
On the value of this compensation, sources vary widely (Lal 1834: 77; Biddulph 1880: 133; Hughes 1883: 408; Azar 2006: 23; cf. also Klimburg 7879fn.; Palwal 1977: 86-87), evidently reflecting the fact that, rather than being uniformly fixed for all as Robertson (1896: 533) reported, the penalty was negotiated through the elders as Azar relates, and depended on the circumstances of the violation, as well as on the relative status of the parties involved. Our elders' indication of the amount of four tūmān $n^{7}$ should probably be taken as an extreme possibility, rather than a fixed rule of any kind.

As for the damage to the culprit's property, that would also probably be an occasional occurrence, if the forms of the offence were such as to raise a wave of indignation in the community, as in Robertson's (1896: 443-444) anecdote where the arrogant maltreatment of the husband by the offender caused a crowd to storm his house and raise it to the ground. The ordeal described in the interview is a unique testimony. The only other source dealing with the issue of proof in the absence of damning evidence is Azar (2006: 23-24), who does not report this particular method.

Altogether we may conclude that, while attitudes about adultery and its sanctions may have varied widely in time and space, as a rule the women must have enjoyed a considerable margin of freedom in entertaining extra-marital relationships, since consequences for themselves were not so frightful and even the risk for their partner was not a matter of life and death. If we further consider Robertson's (1896: 533) suggestion that "public opinion" was all in favour of "gallantry", the women's elbow room in sexual matters would appear even greater than in so-called "modern" contexts.

[f. 16b] If a girl (dukhtar) does bad things before her marriage, how is she punished?

[f. 18a] There is no punishment for the girl who has sex (zinā kard) with someone [before marriage].

\footnotetext{
${ }^{7}$ It is hard to tell exactly what this figure might have meant at that particular time and place, but, since a tūmān was theoretically worth 10,000 dinars, the amount must have been substantial. At any rate, though money was occasionally referred to in Kafiristan as a measure of value, it was hardly ever used as an actual means of payment (cf. Cacopardo, apud Azar 2006: 8fn.).
} 
This is an important statement by Tak and Shamlar, because most sources are silent about pre-marital sex, and Robertson (1896: 534) is perhaps the only one who mentions it: "If an unmarried girl were found to be misconducting herself, she would probably be only scolded by her parents, and the matter would be hushed up". Of course there is the problem of what exactly is meant by "before marriage": it seems likely that our elders' statement here refers not to the time of the agreement, but to the later moment when the bride actually moved to her husband's home, leaving much room to the "very immoral" behaviour of young women, which Robertson (1896: 533), with a sudden burst of ethnographic intelligence, offered to excuse by explaining that this is "not because their natural average disposition is either better or worse than that of women of other tribes and races", but because of that general "favour for gallantry". To put it in other words, "free love" was quite accepted.

[f. 16b] Can women repudiate (țalāq bigīrand) their husbands?

[f. 18a] Women are happy with satisfying their husband and divorce is bad.

Having been very frank about pre-marital experiences, Tak and Shamlar seem perhaps more reticent about the women's freedom to change husbands. Their answer seems to indicate that at their time in Kamdesh, elopement did not enjoy in society the central role of alașing among today's Kalasha. Permanent elopement, indeed, is hardly mentioned by any other author. Yet, we do know from Robertson that it did occur in his time: in his version, there was no fixed and uniform compensation as with the Kalasha, but the husband would try hard "to get an enhanced price for his fugitive wife" (Robertson 1896: 536). At any rate, it must be noted that while in the case of repudiation by the husband, Tak and Shamlar were firm in excluding it, here they do not state that the instance is ruled out, but only that it is "bad". This would suggest that elopement did occur, but not quite as smoothly as among present-day Kalasha (cf. Parkes 1983: 59698).

[f. 16b] When girls get married, is that because of love ( $a z$ 'āshiqü) or of their mother's and father's decision?

[f. 18a] Daughters can also choose their husband out of love (ba 'āshiqī), but they generally get married to the satisfaction of their mother and father. 
Here Tak and Shamlar appear to soften their previous spontaneous statement about resistance to arranged marriages, by presenting a picture of general harmony between parents and child-yet, they do confirm that the girl has freedom of choice: this is where "love marriage" makes its explicit appearance.

[f. 16b] Are women brave or not?

[f. 18a] Women are very courageous.

This statement projects an ideal image of women's self-reliance that contrasts sharply with Robertson's $(1896: 530,535)$ grim picture of women as "household slaves" and "really a chattel".

[f. 16b] Are there girls who would oppose (i'rä̇ mīkunand) their own marriage?

[f. 18a] If a daughter does not like someone, she cannot be forced to take him, and if

her mother and father force her to marry she will kill herself.

Here we have the most conclusive statement about the principles of marriage decisions: she cannot be forced to take him, that would mean to kill her. At least in the vision of our elders, the woman's will is the sovereign in this matter.

We must conclude. In Tak and Shamlar's Kamdesh, the women's agency in the sphere of sex and love seems hardly any weaker than with today's Kalasha. They were free to make love in their youth, and they did not risk death with adultery. Though alașing was apparently not quite a "recognized right", perhaps the conventional threat of suicide was no less effective than the actual option of elopement in affording them the luxury of love marriage. Does this taste like "modernity"?

When Charles Masson (1842: 227) wrote that among Kafirs "[m]arried women are distinguished from virgins by wearing a ring in the right ear", we may smile at his taking for granted that unmarried women would be virgins. The Victorian frame of mind of all those authors belongs to our past. The object they were describing, instead, had something of their future. For once, in that encounter, the "Rest" looks like the future of the "West".

\section{ACKNOWLEDGEMENTS}

The article is, in its entirety, the result of the collaboration of the two authors; however, for official use, the first half is to be attributed to Alberto Cacopardo and the second half to Stefano Pellò. 


\section{BIBLIOGRAPHY}

Azar, M. A. K. (2006), My Heartrendingly Tragic Story, A. M. Cacopardo/R. L. Schmidt (eds.), Oslo.

Biddulph, J. (1880), Tribes of the Hindoo Koosh, Calcutta.

Cacopardo, A.M. (2019), Chi ha inventato la democrazia? Modello paterno e modello fraterno del potere, Milan.

_ (in press), "Peristan: The Counter-Civilization of the Hindukush/Karakorum. The State of Ethnohistorical Research", International Journal of Diachronic Linguistics and Linguistic Reconstruction, 19 [forthcoming in 2022].

Cacopardo, A. M./Cacopardo, A. S. (2001), Gates of Peristan. History, Religion and Society in the Hindu Kush, Rome.

—_Pellò, S. (forthcoming), The "Ā'inn-i Käfirān" by Häjī Allāhdād: A Persian Ethnography on the "Kafirs" of the Hindukush (ca. 1840), Rome.

Court, C. A. (n.d.), "Notice sur le Kafféristan dressée sur la demande qui m'en fut faite par la Societé asiatique de Paris", Mémoires, vol. 4: 81-104. [Unpublished manuscript, Musée Guimet, Paris, ca. 1840.]

Elphinstone, M. (1815), An Account of the Kingdom of Caubul, and its Dependencies in Persia, Tartary, and India, London.

Graeber, D. (2007), Possibilities. Essays on Hierarchy, Rebellion and Desire, Oakland.

Grey, C. (1929), European Adventurers of Northern India 1785 to 1849, Lahore.

Holzwarth, W. (1994), "Sich verständlich machen. Tak und Shamlar aus Kamdesh beantworten einen Fragebogen des Generals Auguste Court zum 'kafirischen Lebensstil”, C. Elsas et al. (eds.), Tradition und Translation. Zum Problem der interkulturellen Übersetzbarkeit religiöser Phänomene. Festschrift für Carsten Colpe zum 65. Geburtstag, Berlin: 179-99.

Hughes, T. P. (1883), "Kafiristan, nach den Berichten des Missionars Hughes und des Afghanen Munschi Syud Schah”, Petermanns Geographische Mitteilungen 29: 404-409.

Jones, S. (1974), Men of Influence in Nuristan, London.

Klimburg, M. (1999), The Kafirs of the Hindukush. Art and Society of the Waigal and Ashkun Kafirs, vol. I: Text, Stuttgart.

Maggi, W. (2001), Our Women Are Free. Gender and Ethnicity in the Hindu Kush, Ann Arbour.

_-(2006), “'Heart-Stuck': Love Marriage as a Marker of Ethnic Identity among the Kalasha of Northwest Pakistan", J. S. Hirsch/H. Wardlow (eds.), Modern Loves: The Anthropology of Romantic Courtship and Companionate Marriage, Ann Arbor: 78-91.

Masson, C. (1842), Narrative of Various Journeys in Balochistan, Afghanistan and the Panjab including a Residence in Those Countries from 1826 to 1838 , vol. 1, London.

Lafont, J.-M. (1992) La présence française dans le royaume sikh du Penjab 1822-1849, Paris.

- (2000) Indika. Essays on Indo-French Relations 1630-1976, New Delhi.

Lal, M. (1834), "Further Information regarding the Siah Posh Tribe, or Reputed Descendants of the Macedonians", Journal of the Asiatic Society of Bengal 3: 76-79. 
Palwal, A. R. (1977), The Kafir Status and Hierarchy and Their Economic, Military, Political and Ritual Foundations, Ph.D. thesis, The Pennsylvania State University, Department of Anthropology.

Parkes, P. (1983), Alliance and Elopement: Economy, Social Order and Sexual Antagonism among the Kalasha (Kalash Kafirs) of Chitral, Ph.D. thesis, University of Oxford, St. Anthonyùs College, Oxford.

Pellò, S. (2009), "Massoni o manichei? Immaginario etnografico sui Kafiri dell'Hindu Kush", Hiram. Rivista del Grande Oriente d'Italia 2: 95-104.

Robertson, G. S. (1896), The Kafirs of the Hindu Kush, London. 